\title{
Screening of Termiticidal Activities Different Extracts of Stem Bark of Prunus africana against Macrotermes spp.
}

\author{
Desta Dirbeba \\ School of Natural and Computational Science, Dire Dawa University, Dire Dawa, Ethiopia \\ Email address: \\ destad24@gmail.com \\ To cite this article: \\ Desta Dirbeba. Screening of Termiticidal Activities Different Extracts of Stem Bark of Prunus africana against Macrotermes spp. American \\ Journal of Applied Chemistry. Vol. 6, No. 1, 2018, pp. 35-38. doi: 10.11648/j.ajac.20180601.15
}

Received: December 18, 2017; Accepted: January 10, 2018; Published: January 26, 2018

\begin{abstract}
Prunus africana is renowned for its durability which can be attributable to the presence of wood extractives that are poisonous to degrading organisms such termites and fungi. The present study was thus undertaken to examine the potential termiticidal activity of different extracts of stem bark of Prunus africana against Macrotermes spp. The bark was extracted using different solvents (petroleum ether, diethyl ether and chloroform) and each extract was tested at seven different concentrations $(0.156,0.313,0.625,1.250,2.500,5.00$ and $10.00 \mathrm{mg} / \mathrm{mL})$. The results revealed that the diethyl ether extract is potent termiticide against the termites with lethal concentration of $0.22 \mathrm{mg} / \mathrm{mL}$ within 5 minutes.
\end{abstract}

Keywords: Prunus africana, Macrotermes, Termiticidal Activity

\section{Introduction}

Prunus africana (Hook. f.) Kalkman (Rosaceae) is a multiple use tree species with local and international economic and medicinal value. The species is popular for its bark whose extract is used to treat benign prostate hyperplasia which is anon-cancerous enlargement of prostate common in men over the age of 50. The plant is widely used in traditional medicine in southern, eastern and central African countries $[1,2]$. Traditional healers across Africa use Prunus africana (P. africana) as a medicine to treat diarrhea, dysmenorrheal, epilepsy, impotence, infertility, irregular menstruation, kidney disease, mental illness, eye disorders, fevers, obesity, pneumonia, arthritis, hemorrhage, hemorrhoids, hyper menorrhea, hypertension and prostate gland enlargement. Its extracts have also been used as antibacterial, anti-inflammatory, antimalaria, antiparasitic and antirheumatic. Additional to the medicinal value, the high strength and durability of $P$. africana timber makes it a useful tree throughout its natural range $[3,4]$.

In Ethiopia, the traditional healers use infusions of leaves, decoctions of stem and root barks of the plant to treat urinary disorders, diarrhea, stomach ache, ascariasis, wound dressing and bacterial diseases such as gonorrhea $[5,6]$.

On the other hand, wood of Prunus africana is renowned for its durability which can be attributable to the presence of wood extractives that are poisonous to degrading organisms. Wood extractives are found in the heartwood and bark of some tree species and they are one of the main reasons for resistance of wood against termite and fungal attacks. The content of extractives plays a key role in the prediction of the durability of wood. Wood extractives are composed of various chemicals which render wood poisonous to degrading organisms $[3,5]$. Therefore, screening of extract of the plant for their termiticidal activity is essential for ascertaining the durability of the plant to its termite toxicity or repellent capability. This provided an impetus for the evaluation of termiticidal activity of the stem bark of the $P$. africana against Macrotermes ssp.

Wood decay fungi and some species of termites are potent wood destroying organisms attacking various components of the wood. Termites cause significant losses to annual and perennial crops and damage to wooden components in buildings. Damage caused by subterranean termites, historically has been a concern of researchers worldwide [7]. Termites are among the worst pests for wooden structures and objects and their presence may also represent a serious threat for cultural heritage especially in those areas where climate and environmental conditions are especially favorable to these insects [8].

Although synthetic pesticides remain the primary method used to prevent termite attack on wooden structures, the 
increased environmental regulation and a desire for the decreased synthetic chemical dependence have aroused interest in the use of naturally occurring termite toxicants; feeding deterrents and repellents [9]. Extractives contained within woods and barks are toxic or deterrent for termites, bacteria and fungi resistance. Termite resistance of wood is a function of heartwood extractives as a result of which extractives from woods and barks having termite resistant activity have been under investigation for many years [10].

The protection of wood against biodeterioration is related to its chemical composition mainly due to the accumulation of extractives in the heartwood. Wood extractives are nonstructural wood components that play a major role in the susceptibility of wood against wood decay organisms [11]. The relationship between extractives and natural durability of wood was first reported in 1924 after which dozens of studies have shown that extractives have major role for natural durability of wood. The natural durability of wood is often related to toxicity or repellent nature of extractive components against termites, fungi and bacteria [12].

Thetemites of Macrotermes spp. are a member of fungus growing family of Macrotermitinae and family of Termitidae. They impact economy of a country negatively by causing damage to various agricultural crops, lands, wooden portion of building, furnitute, books, uitlity poles and fence poles in several parts of africa [13]. Synsthetic chemicals are the most commonly used as a control measure agaist such harmful pests. However, most sythentic pesticides are not enviromentally friendly and often have adverse effects on non-target organisms. Thus, the search of botanical extracts with termiticidal activity has paramount importance as they are ecofriendly.

\section{Method}

\subsection{Sample Collection and Preparation}

\subsubsection{Sample Collection and Authentication}

The stem bark of $P$. africana was collected from Wonago Woreda of Gedeo Zone in South Nations, Nationalities and People's Regional State from four particular sites namely Balebuksa, Tikrese, Sokcha and Sugale. The area was selected mainly based one ethno botanical literature survey that the plant has been used for medicinal purpose in the area. The leaves were pressed and authenticated by Addis Ababa University National Herbarium. The specimen was reserved in the National Herbarium with specimen code of DD-001.

Even though the plant has capability to regenerate after debarking, complete stripping off the bark may damage the plant. Since the plant is among the threatened species in Africa, the debarking procedure was carried out as recommended by [14]. The samples were collected from mature plants. The collected stem bark sample was brought to Dilla University Chemistry Laboratory in polyethylene bags. The sample was washed with tap water and then with distilled water before it was cut into smaller pieces with stainless steel knife so as to remove dust and other particulates. The pieces were air dried in dark room which had a well circulation of air. The dried plant materials from the four sites were thoroughly homogenized while grinding into fine powder.

\subsubsection{Extraction}

Successive Soxhlet extraction was employed for the extraction of phyto-constituents of the plant. Twenty seven grams of the powdered plant material was weighed on a digital analytical balance. The weighed powdered plant material was placed in paper thimble which was then placed in Soxhlet extractor. Sufficient amount of petroleum ether was placed in $500 \mathrm{~mL}$ round bottom flask. The extraction was continued for 8 hours at rate of 5 cycles per hour the completion of which was signaled by Thin Layer Chromatography (TLC) profile information of the extract. The marc obtained after extraction weighed $24 \mathrm{~g}$ which was then extracted with diethyl ether. This successive extraction was continued in similar fashion until the final residue was extracted with chloroform. Each solvent extract was concentrated under reduced pressure and made ready for the subsequent analysis.

\subsection{The Test Organisms}

Macrotermes species were collected from the mound they have built on a farmer land near Dilla University. The termites were identified by Dilla University entomologists. Termites were maintained in moistened corrugated cardboard rolls in an incubator at room temperature with relative humidity of $96 \%$ in constant darkness and tested two days after of collection.

\subsection{Termiticidal Bioassay}

Preliminary toxicity test was done using $10.00 \mathrm{mg} / \mathrm{mL}$ of each extract of stem bark of Prunus africana (petroleum ether, diethyl ether and chloroform). Toxicity bioassay against Macrotermes spp. was performed according to [15] with slight modification. For evaluation of toxicity of the diethyl ether crude extract against the termites, serial concentrations of the extract were prepared in acetone. The $0.156,0.313,0.625,1.250,2.500,5.000$, and $10.00 \mathrm{mg} / \mathrm{mL}$ prepared solutions were loaded on separate Whatman paper strips cut into the Petri plate size. The loaded sterilized Petri plates were air dried under laminar flow of air to remove the solvent completely. These pre-coated solvent free strips were placed in the centre of separate Petri dishes as tests and Petri plate soaked in acetone but with no loaded extract was used as a control. Green leaves were placed into each Petri plate as food for the termites. Five termites, one queen and four workers, were released into each Petri dish to observe the mortality.

The termites were treated as dead when they become immobile and have shown no further activity to the external stimuli. The observation was continued up to 24 hours and it was made in triplicate. 


\section{Results}

The anti-termite toxicity bioassay of each extract of the stem bark of Prunus africana showed that petroleum ether and chloroform extracts were inactive against the termites while the diethyl ether extract showed some biological activity against the termites. As it is evident in Table 1, the activity of the diethyl ether crude extract against Macrotermes spp. was found to be both time and concentration dependent. The highest and lowest mortality of the termites was observed in the highest and lowest concentrations of the extract respectively. All the exposed termites $(100 \%)$ were dead after 5 minutes except in the concentration next to the lowest concentration, $0.313 \mathrm{mg} / \mathrm{ml}$, under exposure of which only $66 \%$ of the total termites were died after 24 hours. Comparison of number of termite died at $0.313,0.625$ and $1.25 \mathrm{mg} / \mathrm{mL}$ after 2,3 and 4 minutes using ANOVA single factor $(p=0.05)$ showed that there was a significant variation in the number of termite died at mentioned concentrations. This implies that variation in concentration can vary the number of termite died. However, for concentrations $0.625,1.25,2.50$ and $5.00 \mathrm{mg} / \mathrm{ml}$, no significant variation (ANOA, $\mathrm{p}=0.05$ ) was observed among the number of termite died after 2,3 and 4 minutes. Similarly, analysis of variance using ANOVA single factor ( $p$ $=0.05$ ) evidenced that there was no significant variation in the number of termite died at 2.50, 5.00 and $10.00 \mathrm{mg} / \mathrm{mL}$ after 2 and 3 minutes.

Thus, $2.5 \mathrm{mg} / \mathrm{mL}$ is sufficient to kill the termites within four minutes. The number of termite died under concentration of $0.625 \mathrm{mg} / \mathrm{mL}$ at 2,3 and 4 minutes; under concentration of $1.25 \mathrm{mg} / \mathrm{mL}$ at 2,3 and 4 minutes; under concentration of $2.50 \mathrm{mg} / \mathrm{mL}$ at 2,3 and 4 minutes; and under concentration of $5 \mathrm{mg} / \mathrm{ml}$ at 2,3 and 4 minutes was significantly different. Similarly, comparison of number of termite died at 2 and 3 minutes under concentration of 10.00 $\mathrm{mg} / \mathrm{mL}$ showed significant difference ( $\mathrm{t}$-test, $\mathrm{p}=0.05$ ). All these showed that mortality of the termites depends both on time and concentration.

Table 1. Toxicity effect of concentrations of diethyl ether crude extract against Macrotermes sp.

\begin{tabular}{|c|c|c|c|c|c|c|c|c|c|c|}
\hline \multirow{2}{*}{ Conc.mg/ml } & \multicolumn{6}{|c|}{ Number of termite died in 1 minute time interval } & \multicolumn{4}{|c|}{ Number of termite died in 8 hours interval } \\
\hline & 1 & 2 & 3 & 4 & 5 & 6 & $\mathbf{0}$ & 8 & 16 & 24 \\
\hline 0.156 & 0.00 & 0.00 & 0.00 & 0.00 & 0.00 & 0.00 & 0.00 & 0.00 & 0.00 & 0.00 \\
\hline 0.313 & 0.00 & 0.00 & 0.00 & 0.00 & 0.00 & 0.00 & 0.00 & 1.00 & 2.00 & 3.30 \\
\hline 0.625 & 0.00 & 2.67 & 3.67 & 4.00 & 5.00 & - & - & - & - & - \\
\hline 1.250 & 0.00 & 2.67 & 3.67 & 5.00 & - & - & - & - & - & - \\
\hline 2.500 & 0.00 & 3.00 & 3.67 & 5.00 & - & - & - & - & - & - \\
\hline 5.00 & 0.00 & 3.33 & 4.00 & 5.00 & - & - & - & - & - & - \\
\hline control & 0.00 & 0.00 & 0.00 & 0.00 & 0.00 & 0.00 & 0.00 & 0.00 & 0.00 & 0.00 \\
\hline
\end{tabular}

Each value is a mean of replicates, 5 termites were used for each replicate.

\section{Discussion}

The work of [16] provided the scientific proof for the traditional therapeutic use of the plant and showed that the methanolic extract has antibacterial and antifungal activities. The studies of $[11,13,15,18,19 \& 20]$ are similar to this current work in that all of them showed the termiticidal activities of plants' crudes extracts against harmful termites. However, the types of solvents and the test organisms used in those research works are exactly the same with the presents study. Although there are myriads of reports on termiticidal activity of plants and herbs, there is no report on termiticidal activity of this particular plant. Consequently, this work is most probably the first report on the potential termiticidal activity of the plant. The durability of wood of the plant is thus most likely attributable to the presence of wood extractives with termiticidal activity.

\section{Conclusion}

The diethyl ether extract of stem bark of Prunus africana was demonstrated to have ant-termite activity against Macrotermes spp. The $\mathrm{LD}_{50}$ of the diethyl ether extract was found to be $0.22 \mathrm{mg} / \mathrm{mL}$ which indicates that the extract is potent termiticide. Macrotermes spp. have greatest pest potential and causes great loss in agricultural productivity. As a result, persistent organic pollutants (POPs) have been in use in many countries for their management. However, POPs are environmentally unfriendly. Thus, the result is the most probable potential source in finding an environmentally friendly alternative way to persistent organic pollutants for termite management. Further investigation is therefore worthwhile.

Limitation of this Research Work

Although this research study made an attempt to provide scientific evidence for ascertaining durability of Prunus African's heartwood to its termiticidal activity, and provided potential promise for eco-friendly pest management, it has some limitations.

One such limitation is that the termiticidal activity was done only on crude extract of the plant. However, isolation and characterization of the active chemical (s) in the crude extract of would be necessary to determine the exact doze for effective and efficient pest management. As a result further study on isolation and characterization of the active principle in the plant is highly recommended. 


\section{References}

[1] Hostettmann K., Marston A., Ndjoko K. and Wolfender JL. (2000). The potential of African plants as a source of drugs. Current Organic Chemistry, 4: 973-1010.

[2] Stewart KM. (2003). The African cherry (Prunus africana): Can lessons be learned from an over exploited medicinal tree? Journal of Ethnopharmacology, 89:3-13.

[3] Cunningham AB, Mbenkum FT. (1993). Sustainability of Harvesting Prunus africana Barkin Cameroon: A medicinal plant in international trade. People and plants working paper 2.1993; Paris, UNESCO.

[4] Jimu L. (2011). Threats and conservation strategies for the African cherry (Prunus africana) in its natural range. Journal of Ecology and the Natural Environment, 3:118-130.

[5] Dalle G. (2004). Distribution and conservation status of Prunus africana in Ethiopia: opportunities and constraints. 2004; PhD thesis, Georg-August University, Germany.

[6] Mesfin F., Demissew S and T eklehaymanot T. (2009). An ethno botanical study of medicinal plants in Wonago Woreda, Ethiopia. Journal of Ethnobiology and ethomedicine, 5: 1-18.

[7] Schultz TP. And Nicholas D. D. (2002). Naturally durable heartwood: evidence for a proposed dual defensive function of the extractives. Phytochemistry, 54:47-52.

[8] Maistrello L., Martini L., Macias I., Bortolini SN. and Marchettini N. (2011). Evaluation of polyphenols rich natural compounds as treatments to prevent attacks by Subterranean and dry wood termites, Journal of Entomological and $A$ carological Research, 43:261-267.

[9] Rupal AV., Savalia D. M. and Narasimhacharya A. L. (2011). Plant extracts as bio termiticides, electronic journal of environmental sciences, 4: 73-77.

[10] Ohmura W., Doi S. and Aoyama M. (2000). Antifeedant activity of flavonoids and related compounds against the subterranean termite Coptotermesformosanus. Journal of Wood Science, 46: 149-153.

[11] Syofuna A., Banana AY, and Nakabonge G. (2012). Efficiency of natural wood extractives as wood preservatives against termite attack. Maderas, Cienciay Tecnología, 14(2):155-163.
[12] Taylor AM, Gartner BL and Morrell JJ (2006). Effects of heartwood extractive fractions of Thujaplicata and Chamaecyparisnoot katensison wood degradation by termites or fungi. Journal of Wood Science, 52:147-153.

[13] Addisu S., Mohamed D. and Woktole S. (2014). Efficacy of Botanicals Extracts against Termites Macrotermes spp. under Laboratory Conditions, International Journal of Agricultural Research, 9(2), 60-73.

[14] Munoz C., Africa M., Cerrillo N., Maria R., Kasimis MR., Bermejo NH., Esteban J., Cedres P., Fernandez EM., Clemente EH., Porras RF. (2006). Evaluation harvest of the of Prunus Africana barkon Bioko (Equatorial Guinea): guidelines for a management plan, University of Cordoba, Spain. ISBN84-7801-848-4, DLCO-1464.

[15] Ahmad B., Khan I., Bashir S., Azam S. and Ali N. (2011). Screening of Acaciamodesta for antifungal, anti termite, nitricoxide free radical scavenging assay and brine shrimpcyto toxic activities. Journal of Medicinal Plants Research, 5, 3380-3386.

[16] BiiK, Korir R. Rugutt J and Mutai C. (2010). Prunus africana for the control, treatment and management of common fungal and bacterial infections. Journal of medicinal plants research, 4:995-998.

[17] Singh N and Kumar S. (2008). Antitermite activity of Jatrophacurcas Linn. Biochemicals, Journal of Applied Sciences and Environmental Management, 12: 67-69.

[18] Abbas M, Shahid M, Iqbal M, Anjum F, Sharif S, Ahmed Sand Pirzada T (2011). Antitermitic activity and phytochemical analysis of fifteen medicinal plant seeds, Journal of Medicinal Plants Research, 7, 1608-1617.

[19] Manzoor F., Beena W., Malik S., Naz N., Naz S and Syed WH (2011). Preliminary evaluation of Ocimumsanctumas toxicant and repellent against termite, heterotermesindicola (wasmann) (Isoptera: Rhinotermitidae). Pakistan journal of science, 63:59-62.

[20] Abbas M., Shahid M., Iqbal M., Anjum F., Sharif S., Ahmed S. and Pirzada T (2013). Antitermitic Activity and Phytochemical Analysis of Fifteen Medicinal Plant Seeds, Journal of Medicinal Plant Research, 7(22), 1608-1617. 